\title{
Integrated maritime policy for the European Union - consolidating coastal and marine information to support maritime spatial planning
}

\author{
Andrus Meiner
}

Received: 19 January 2009/Revised: 19 October 2009/Accepted: 20 October 2009 / Published online: 10 November 2009

(C) Springer Science + Business Media B.V. 2009

\begin{abstract}
Launch of the Integrated Maritime Policy for the European Union in 2007 served as important factor that stimulates consolidation of coastal and marine information to support policy implementation. Policy's action plan provides approaches for maritime governance, research and planning relevant to information. In particular, roadmap for maritime spatial planning stimulates development of coastal and marine GIS. Article reviews the current general status of coastal and marine systems and puts them in the context of the policy actions. Main focus is on formation of geospatial information platform for integrated assessment and ecosystem-based management of coastal and marine areas. Recent developments in data, indicator and information systems are summarized in European perspective: better characterization of maritime space and marine ecosystems, development of GMES Marine Core service and related in situ data collection; data harmonisation, interoperability and access, promoted by Shared Environmental Information System principles.
\end{abstract}

Keywords EU maritime policy · Coastal atlases · GIS . Maritime spatial planning $\cdot$ Indicators

\section{Introduction}

The seas and coasts of Europe are a vital resource which millions of people depend, both economically and for their

The analysis and views presented in this paper should be taken as the personal perspective of the author and cannot be regarded as the official position of the European Environment Agency.

\section{A. Meiner $(\square)$}

European Environment Agency,

Kongens Nytorv 6,

1050 Copenhagen, Denmark

e-mail: Andrus.Meiner@eea.europa.eu quality of life. They also provide a wide range of ecosystem services that are essential to the health of the environment in Europe. Where phenomena of environmental deterioration are observed, important lessons are learned. Many scientific studies conducted in Europe and the world show signs of changes for a variety of coastal and marine ecosystems that suggest a loss of resilience: the ability of an ecosystem to survive under the influence of pressure and changes they exercise. The new emerging ecosystem-based management approach requires relevant methods for data collection, monitoring and assessment of our seas and coasts.

The World's continental shelf waters have been organised in to 64 Large Marine Ecosystems (Sherman et al 1993). In parts more disaggregated, quite similar division system is provided by 232 marine eco-regions (Spalding et al. 2007) of which about 20 can be regarded as European. Both approaches are related and emphasize on-going paradigm shift in marine management characterised by multiple scales, long-term perspective and adaptive management that is oriented on sustaining ecosystems and their production potential for goods and services.

A Global map of cumulative human impact (Halpern et al. 2008) across 20 ocean ecosystem types indicates NorthWestern European seas having large proportion of very high impact areas. Recent global assessment of harmful non-native marine species known to be established in each marine eco-region indicates European seas as particularly affected (Molnar et al. 2008). World Resources Institute have assessed (Selman et al. 2008) the extent of coastal eutrophication and hypoxia in 415 coastal areas around the World. They found 169 areas being hypoxic, Europe having largest cluster of areas of concern.

Despite alarming state of European seas the pressures on marine ecosystems are expected to increase. Most of 
European coastal countries have determined the limits of their maritime rights and jurisdiction exercised under UN Convention on the Law of the Sea (Exclusive economic zones). On the basis of Part VI on the Continental Shelf and Part XI on the Area of the UNCLOS and following the rules set up by the Commission on the Limits of the Continental Shelf, by May 2009 several coastal states submitted claims for extending the outer limits of the continental shelf beyond EEZ limit (albeit only with regard to the seabed and the marine subsoil).

The geographical, ecological and territorial dimension of Europe's coastal and marine environment is gaining increasing attention by policies, as illustrated by the implementation of Natura2000 network (marine and coastal habitats and marine protected areas), the evaluation of ICZM Recommendation, the review of Common Fisheries Policy, Water Framework Directive (including coastal and transitional waters), the Marine Strategy Framework Directive and the EU Integrated Maritime policy.

Taking an ecosystem-based approach to organise the coastal, marine and maritime activities implies integration of geospatial data and the support to relevant spatial analysis of environmental issues and socio-economic pressures. New challenges in spatial information acquisition are related to incorporation of relevant Earth observation services and the need for broad-scale characterisation of marine habitats and seabed landscapes, in particular as basis for a representative data model of the maritime space and its formation as a geographic information system (GIS).

There is a need to focus on coastal/maritime assessment activity with the particular objective of analysing the spatial distribution of natural and human features and their related dynamics (key processes of change, sustainability of socio-economic development, vulnerability and adaptation to environmental change etc.). Conflicts among different uses of maritime space arise between nature and man or economic activities themselves. Leading to inefficiency and waste of resources, these situations are often the result of insufficient information about presence of vulnerable assets or intensity and distribution of socio-economic activities.

Quantitative and qualitative assessments of coastal ecosystem services over space and time will allow better understanding changes in the use of coastal zones and maritime space. This should also include prospective analysis of issues such as tourism and urban sprawl, ports and maritime transport, as well as the impacts of climate change and options for adaptation. In particular EEA is aiming at the development of relevant spatial data and analysis (EEA 2006a) and ecosystem accounting (EEA 2008) as a method to help achieve the objectives above.

\section{EU Integrated Maritime policy}

Following decisions made in the European Commission's Strategic Objectives for 2005-2009 about establishment of a new European integrated maritime policy the Commission has put forward a new vision for Europe's oceans and seas.

The new integrated maritime policy applies to the oceans and seas a holistic, integrated approach and promise replace compartmentalised resource management approach with an ecosystem based management view. New policy aims to tackle all maritime activities and sustainable development aspects of the oceans and seas, including the marine environment, in an overarching fashion:

- Applying the integrated approach to maritime governance

- Developing tools for integrated policy-making

- Maximising the sustainable use of the oceans and seas

- Building a knowledge and innovation base for the maritime policy

- Delivering the highest quality of life in coastal regions

- Promoting Europe's leadership in international maritime affairs

- Raising the visibility of maritime Europe

Preceded by successful involvement of stakeholders during the consultation process of the Green Paper (European Commission 2006a) on 10 October 2007, the European Commission adopted the Blue Paper proposing an Integrated Maritime Policy for the EU (European Commission 2007a), and a detailed Action Plan (SEC (2007) 1278). The European Council endorsed the IMP and the Action Plan on 14 December 2007.

IMP Blue paper is announcing some strategic initiatives that serve as foundation for more detailed implementation steps in the Actions plan:

- Create barrier-free European Maritime Transport Space.

- Overall strategy for EU ports.

- Commission's Communication on strategic reflection on the future of EU Maritime Transport in the horizon 2008-2018.

- European Strategy for Marine and Maritime Research.

- EU funding for Europe's coastal regions.

- Planning of coastline (ICZM).

- Environmentally-friendly shipping, ecosystem-based fisheries, eliminate illegal fisheries.

- New Maritime Planning Tools (MSP).

- Surveillance systems, compliance and law enforcement.

Assuming a broader context across 10 existing EU policy areas the overall maritime policy aims to foster economic and social sea-related opportunities in the context of a sustainable use of the seas.

Action plan reflects the new integrated approach to maritime affairs, covering a wide spectrum of issues 
ranging from maritime transport, to the competitiveness of maritime businesses, employment, scientific research and the protection of the marine environment (Table 1):

In its conclusions of 8 December 2008 the Council recognised that implementation of European Integrated Maritime Policy is on good track, notably on key issues such as governance, surveillance, and research (Council 2008). The Council equally recognised the work done so far on maritime spatial planning and offshore renewable energy, as well as the work towards developing specific strategies for different maritime basins, i.e. for the regions of the Baltic Sea and the Arctic.

The European Commission reported the progress on the EU's Integrated Maritime Policy in October 2009. The implementation of the Action plan has progressed well: of the 65 actions in the plan 56 has been launched (mostly in the form of formal acts) and on remaining 9 actions various initiatives have been taken (European Commission, 2009b). Essentially, the framework provided by the IMP is following four objectives: 1) promoting integration of governance structures; 2) building the knowledge base and cross cutting tools; 3 ) searching actively for synergies and increased coherence across sectoral policies; 4) implementing the IMP actions through specific solutions in the context of regional marine regions.

In particular, maritime spatial planning, in combination with increased marine knowledge, can provide confidence for economic investments and drastically improve the way we manage our maritime spaces, preserving their ecosystems. It must become a practical instrument on all relevant levels of governance.

\section{Governance}

For implementing Integrated Maritime Policy the European Commission proposes guidelines for national maritime policies that promote best practice in integrated maritime governance and stakeholder consultation policies (European Commission 2008a). The guidelines offer for the Member States an integrated approach to enhance joint-up maritime governance, inviting the governments to draw up their own integrated national maritime policies, based on a series of common principles and working closely with their stakeholders, in particular the coastal regions.

The guidelines outline the framework of needs and drivers for an integrated approach to maritime governance and serve as prerequisite for a common information platform. They provide a clear response to achieve greater coherence between different policy areas and approaches, taking particular account of some requirements relevant to streamlined data collection and better information base for decision making:

- the need to avoid duplication of regulatory powers of different national or regional authorities in the Member States;

- the acknowledged need for coordinated planning of competing maritime activities and for strategic management of maritime areas (maritime spatial planning); - the adoption and implementation of the ecosystem approach and the Marine Strategy Framework Directive; - the need to develop an interface between science and policy and to ensure that marine science is able to inform maritime policy;

- the need for reliable and comparable statistics to inform maritime policy making on all levels;

- the need to facilitate closer coordination on maritime surveillance between, and within, Member States.

By offering the principles listed above, the guidelines create a linkage between maritime knowledge base (research and statistics), maritime spatial planning (role of coastal regions in coordinated planning) and the ecosystem approach (marine strategy). The latter, enshrined in the recently adopted Marine Strategy Framework Directive, requires that large, transfrontier marine ecosystems must be preserved in order to maintain the resource base of all maritime activities. Within this context of marine environmental protection, it is therefore necessary also to think in terms of maritime basins and the marine regions and subregions provided for in the Directive.

There has been a rapid increase in sea-related activities with clear potential for conflicts of use. Development and
Table 1 Integrated maritime policy Blue book: key policy areas and types of actions

\begin{tabular}{ll}
\hline Key policy areas & Types of actions \\
\hline Integration & policies, guidelines, consultations \\
Tools & surveillance, monitoring, control, data, spatial planning \\
Sustainable growth & transport, employment, environment, fisheries \\
Research and Innovation & research strategy, cross-cutting calls, science partnerships \\
Coastal Life & tourism, regional funding, risks, islands \\
European leadership & shared seas, external relations \\
Visibility & "European Maritime Day" May 20th Atlas of the Seas, \\
& maritime identity and heritage \\
\hline
\end{tabular}


use of specific marine planning tools at the appropriate levels is therefore widely recognised. These planning tools, in turn, can only be built on an integrated approach to maritime governance that involves all government levels - EU Institutions, Member States, coastal regions, and stakeholders.

\section{Knowledge base}

The Commission adopted a European Strategy for Marine and Maritime Research to step up co-operation between researchers and to develop the governance necessary to make this possible. The Strategy suggests developing a partnership of stakeholders - scientists, policy-makers, industry and civil society - to agree on priorities and develop joint programming to achieve steady progress that builds on previously completed results made widely accessible. The respective communication (European Commission 2008b) provides the list of major research topics requiring a cross-thematic approach:

- Climate change and the oceans - enhanced detection and better assessment of the impacts of climate change on oceans and on coastal areas.

- Impact of human activities on coastal and marine ecosystems and their management - mitigation of the cumulative effects of land-based as well as maritime activities.

- Ecosystem approach to resource management and spatial planning - optimise the management of marine and maritime activities and their sustainable development.

- Marine biodiversity and biotechnology - more knowledge on the functional role, evolution, protection and exploitation of marine biodiversity.

- Continental margins and deep sea - enhanced understanding of deep-sea sediments, ecosystems and observation needs.

- Operational oceanography and marine technology advance in the development of marine core services within the GMES.

- Exploitation of marine renewable energy resources more knowledge on how to exploit the potential of offshore wind, ocean currents, wave and tidal movements.

The Commission is proposing the launch of a new governance model for research that will take the form of a "Forum" bringing together a "partnership sustainable over the long term", involving existing networks and all key partners in the marine and maritime research and industrial sectors. The "Forum" should update the research priorities on a continuous basis and identify gaps, implement new forms of cooperation, financing schemes and exploitation of research results. Relevant to this proposal, the European Coastal, Marine and Maritime platform has been initiated by respective networks of researches and practitioners (Venice, Nov 2008).

Maritime spatial planning

Increased activity on Europe's seas leads to competition between sectoral interests, such as shipping and maritime transport, offshore energy, ports development, fisheries and aquaculture and environmental concerns. To implement the Integrated Maritime Policy a more collaborative and integrated approach to decision-making is required to secure the sustainable development of marine areas in a healthy environment.

The European Commission's roadmap for maritime spatial planning (European Commission 2008c) provides information on current practices in EU Member States and in third countries, outlines the instruments which impact upon it and sets out key principles underpinning it. By providing a roadmap the Commission seeks to encourage a broad debate on a common approach to maritime spatial planning (MSP).

By proposing a framework for arbitrating between competing human activities and managing their impact on the marine environment the MSP is aiming to provide a tool for improved decision-making and therefore creates expectancy for more coherent information base. Following ecosystem-based management approach the MSP should be based on the specificities of individual marine regions or sub-regions. This will also promote the efficient use of maritime space and cost-efficient adaptation to the impact of climate change in maritime areas and coastal waters.

Maritime spatial planning can be implemented through various instruments of which zoning is only one possible option. MSP is much more than a concept - it is a process that consists of data collection, stakeholder consultation and the participatory development of a plan, the subsequent stages of implementation, enforcement, evaluation and revision. Therefore, the adoption of a maritime spatial plan represents a highlight, but requires systematic information collection and exchange on all phases of this process.

While there certainly are some similarities with land use planning (both make use of plans to reconcile competing claims for space), there are also significant differences including: (a) the dimensional aspect as MSP must address activities on the seabed, in the water column and on the surface; (b) the mobile nature of many maritime activities (such as fishing and navigation) which use space but not permanent structures; and (c) the fact that land use planning takes place against a common background of private land tenure rights which do not have a maritime equivalent. Instead maritime activities are regulated through a range of sectoral laws, plans and licences/permits (European Commission 2008d). 
MSP provides a basis for Member States to develop, in conjunction with other instruments such as environment legislation or impact assessments of integrated management plans for specific sea basins or ecosystems. A growing number of EU Member States have already launched maritime spatial planning measures or will soon be doing so, for example integrated management strategies for their sea areas that are directly relevant to MSP. The approaches vary significantly, but MSP plays in all these documents an important role to implement a coordinated approach to the allocation of marine space. So far there are three main types of activities (Schäfer 2008):

1. Maritime spatial plans will become of statutory nature on the basis of extending terrestrial planning law to marine areas (e.g. Germany);

2. Strategic or integrated management plans that provide overall framework and aim to give guidance for both existing and new maritime activities regarding sustainable use of marine resources (e.g. the Netherlands, Norway);

3. National framework laws (marine bills) to implement a national integrated maritime policy and to steer future maritime development in sustainable way (e.g. UK and Scotland, Sweden adopted in 2009).

Following the European Integrated Coastal Zone Management Strategy (European Commission 2000) and EU ICZM Recommendation (Council 2002), several Member States and regions have started to implement ICZM strategies that could be of relevance to the MSP (European Commission 2007b). Commission's Blue paper on IMP also recommended setting up a system for exchange of best practices in developing ICZM that has resulted in action to prepare a knowledge platform for sharing best-practice and promoting effective implementation of ICZM.

While implementation of maritime spatial planning is the responsibility of Member States, there is an added value for action at EU level. Coordination between Member States will benefit the ecosystem as a whole and also can lead to more balanced long-term management on sea and land. The EU's role is to facilitate understanding and coordination between Member States in order to tackle common challenges such as climate change, energy security and economic development. Member States sharing a common approach to the management of marine space in the same sea basin will find it easier to meet these challenges.

The MSP roadmap marks a first step, by way of a debate, towards the development of a common approach to maritime spatial planning as an important tool for the implementation of the EU's Integrated Maritime Policy. The main element of roadmap that requires consultation with stakeholders is set of ten common principles of relevance to the MSP in the EU:

Key principles emerging from maritime spatial planning practice (European Commission 2008c):

1. Using MSP according to area and type of activity

2. Defining objectives to guide MSP

3. Developing MSP in a transparent manner

4. Stakeholder participation

5. Coordination within Member States - simplifying decision processes

6. Ensuring the legal effect of national MSP

7. Cross-border cooperation and consultation

8. Incorporating monitoring and evaluation in the planning process

9. Achieving coherence between terrestrial and maritime spatial planning - relation with ICZM

10. A strong data and knowledge base

Perspectives for offshore renewable energy can serve as example how development of maritime industries is becoming part of integrated vision of maritime spatial planning. The Commission has adopted a Communication on Offshore Wind Energy (European Commission 2008e) which identifies the challenges to be tackled in exploiting Europe's potential for offshore wind energy, and how EU action can help in meeting these challenges. Among key themes is a need for genuinely integrated maritime spatial planning that could provide a framework for balancing and arbitrating between different sectoral interests, provide optimal solutions for protected species and habitats (e.g. environmental impact assessments of wind farms) and set stable conditions for investments. Further steps foresee, among others, encourage the Members States to implement maritime spatial planning to regulate the competing and growing uses of the seas, including off-shore renewable energy.

Only a few European countries currently have defined dedicated offshore wind areas including the UK, Germany, Denmark Belgium and the Netherlands, each of which has its own approach (EWEA, 2009). Absence of an integrated strategic planning and cross-border cooperation for maritime spatial planning between the different member states and regions also remains a challenge to the deployment of offshore power generation.

The scope of MSP in terms of geographic coverage will differ according to regional conditions. There is a role to play for coastal regions and other sub-national decisionmakers at regional and local levels. Coastal regions not only benefit from an integrated approach to maritime policy, but also run the largest risks in the absence of coherent sea-related policies. In view of their close relationship with the sea, several coastal regions are developing their own integrated strategies, tailored to their specific needs. Within Member States, they may often be 
responsible for Integrated Coastal Zone Management or to regulate the spatial deployment of economic activities. As they often have unique know-how and insights and represent key interests in maritime issues, they have a role to play in the development of integrated policy-making.

Development of MSP must take into consideration, and where appropriate contribute to, the implementation of several international and EU instruments having direct relevance, notably in the field of the environment. Implementation of the Marine Strategy Framework Directive - the environmental pillar for the European maritime policy - that aims at good environmental status of European seas by 2020 will be particularly relevant in this context. The MSFD makes it necessary for Member States and the Commission to cooperate more at the regional sea basin level and to make best use, where appropriate, of the added value provided by the multilateral regional seas conventions, such as HELCOM, OSPAR or the Barcelona and Bucharest Conventions. The common implementation strategy of the MSFD will create basis for EU compliance check as well as development of relevant indicators and indicator methodologies.

Also, in response to the request made by the European Council on 14 December 2007, the European Commission has prepared the EU Strategy for the Baltic Sea Region (European Commission 2009a, UKIE 2008), which includes measures (i.e. Action plan) to implement an integrated maritime policy for the Baltic which, however, will go beyond maritime policy. The Commission has also started work on a strategy to implement a holistic approach to maritime policy in the Mediterranean. The governance challenge is to optimise efficiency in cooperation in the regional sea basins and to ensure that it adds value to the ongoing work. Regional sea conventions are also looking at innovative instruments of coastal and marine spatial organisation, for example, ICZM Protocol in the Mediterranean (UNEP/MAP 2008) or MSP Recommendation 28E/9 of the HELCOM.

Finally, the Commission has been developing a proposal for measuring progress towards MSP performance in the Member states. The report (European Commission 2008d) also analyse legal constraints of community law and policy developments of economic sectors giving special attention to constraints resulting from horizontal activities such as strategic environmental assessment (SEA).

\section{Coastal and marine information for Europe}

A strong data and knowledge base is listed among key principles emerging from maritime spatial planning practice (European Commission 2008c). This is directly relevant to adaptive management principle where planning needs to evolve with knowledge. Following the IMP Action plan (European Commission 2007a) several activities are started to create information base for the policy implementation and to assist the MSP with scientific and data gathering tools. These include the European Marine Observation and Data Network (EMODNET); an integrated database for maritime socio-economic statistics; the European Atlas of the Seas; and the Global Monitoring for Environment and Security initiative (GMES).

A new integrated analytical approach for our coasts and seas builds on two complementary concepts for data collection and assessment:

- Vision of a marine ecosystem that builds on ecosystembased management approach and integrated marine environment monitoring and assessments.

- Vision of common maritime space that requires holistic approach for development of all sea-related activities in a sustainable manner and better characterization of maritime areas that can assist maritime spatial planning.

\section{Marine Strategy and GMES}

The information collection and analysis in support of marine ecosystem vision is based on the European Marine Strategy (European Commission 2005). The strategy provides framework for implementing an ecosystem-based approach to the management of human activities in the marine environment. Followed Maritime Strategy Framework Directive (MSFD 2008) provided main legislation that requires by 2020 "Good Environmental Status" of the entire marine ecosystem in all European Regional Seas, through regional marine strategies. Directive provides qualitative descriptors that serve as a basis for determining a set of characteristics for good environmental status, in respect of each Marine Region or Sub-Region. Annex III of MSFD provides indicative lists of characteristics, pressures and impacts e.g. variables/determinants relevant for establishing the baseline for marine assessments.

Regional approach to European seas management is adopted at different governance levels, including regional sea conventions. European marine assessments still need further streamlining of information and data flows to allow pan-European analysis of current state and trends. To assist initial assessment of current environmental status of waters and environmental impact of human activities required by 2012 in the MSFD, the member states, regional sea conventions and other stakeholders have worked on European marine monitoring and assessment principles that include a 'converging' set of marine indicators and development of WISE-Marine (marine component of Water Information System for Europe). This process has contributed to development of common implementation strategy of the MSFD.

Relevant cooperation under the Global Monitoring for Environment and Security (GMES) initiative focuses on 
Table 2 Vertical integration and corresponding multi-scale nested data management levels for coastal zone assessment

\begin{tabular}{|c|c|}
\hline Governance level & $\begin{array}{l}\text { Typical land data, spatial } \\
\text { resolution }\end{array}$ \\
\hline \multirow[t]{2}{*}{ Global, pan-European } & GlobCover \\
\hline & GlobCORINE (reclassified) \\
\hline \multirow{2}{*}{$\begin{array}{l}\text { International agreements, } \\
\text { global objectives }\end{array}$} & EuroGlobalMap \\
\hline & $300 \mathrm{~m}$ \\
\hline European market & GlobCORINE \\
\hline National/regional government & $\begin{array}{l}\text { CORINE Land Cover, } \\
\text { EuroRegionalMap }\end{array}$ \\
\hline \multirow[t]{2}{*}{$\begin{array}{l}\text { Policy design and implementation } \\
\text { guidelines, enforcement }\end{array}$} & $\begin{array}{l}\text { GMES High resolution } \\
\text { Land Cover }\end{array}$ \\
\hline & $20-100 \mathrm{~m}$ \\
\hline Local & $\begin{array}{l}\text { GMES High resolution } \\
\text { Land cover, }\end{array}$ \\
\hline \multirow{3}{*}{$\begin{array}{l}\text { Action and policy implementation, } \\
\text { monitoring }\end{array}$} & National data sources \\
\hline & Coastal surveying \\
\hline & $0.1-10 \mathrm{~m}$ \\
\hline
\end{tabular}

Marine Core Service (MCS) that aims for the systematic monitoring and forecasting of the state of marine systems using models and in-situ measurements for physical ocean and primary ecosystems. MSC is currently developed as an EU FP7 integrated research project MyOcean that will provide the common denominator data for all users in the marine sector, in other words the information for existing and new end-user oriented services (MyOcean 2008). Essential components of the MCS are the Thematic Assembly Centers that serve as production units of the GMES Marine Core Services. Large part of data collection, analysis and dissemination in GMES is related to "downstream" services that should be supplied by GMES core services, such as MCS.

GMES develops in three main directions: space, in-situ and services components (European Commission, 2008f). Similarly to the space component the main focus of the in-situ component is to guarantee in the long term easy access to the data necessary for GMES services. In situ component will rely on a large number of facilities, instruments and monitoring systems of non-space infrastructure developed and maintained by the Member States. Overlap and gaps in data availability in marine monitoring programmes need harmonization as well as funding cost-effective data provision. Problems can be related to sufficiency and sustainability of funding as well as intellectual property rights and access restrictions.

Integrated regional approach for coasts and seas

Coastal areas represent the sea/land interface. This is where many use interests overlap creating environmental pressures while natural systems tend to be more sensitive than elsewhere. Competing activities often escalate to conflicts that require a sustainable development perspective. Spatial planning, regional development and territorial cohesion can be seen as integration basis for individual economic, environmental and social (cultural) interests. At the same time any information systematisation attempt at regional or European level must take in to account vertical and horizontal complexity of coastal systems that are present on land and sea. Different levels of administration need multi-scale nested data management, where thematic, temporal and spatial data resolution corresponds to data requirements of specific governance processes (Table 2).

Natural conditions and environmental problems of European coastal and marine regions are highly diverse. Therefore any European information system has to acknowledge this. Several policy processes emphasize importance of ecosystem based or regional approach: marine strategies (by MSFD), role of governance in coastal regions (IMP), bio-geographic regions (EU Habitats directive) or territorial cohesion principles (by Green paper 2008) and EU regional strategies, such as for Baltic, Arctic and Mediterranean (European Commission, 2009c) (Fig. 1).

Following the IMP Blue book the Commission will launch in 2009 a European Atlas of the Seas as an educational tool and as a means of highlighting our common maritime heritage. This action is providing good grounds for promoting an information system for European maritime space, notably by using available spatial information and building on the work of an EMODNET and related IMP preparatory actions, such as development of a European broad-scale seabed habitat map. Experience on

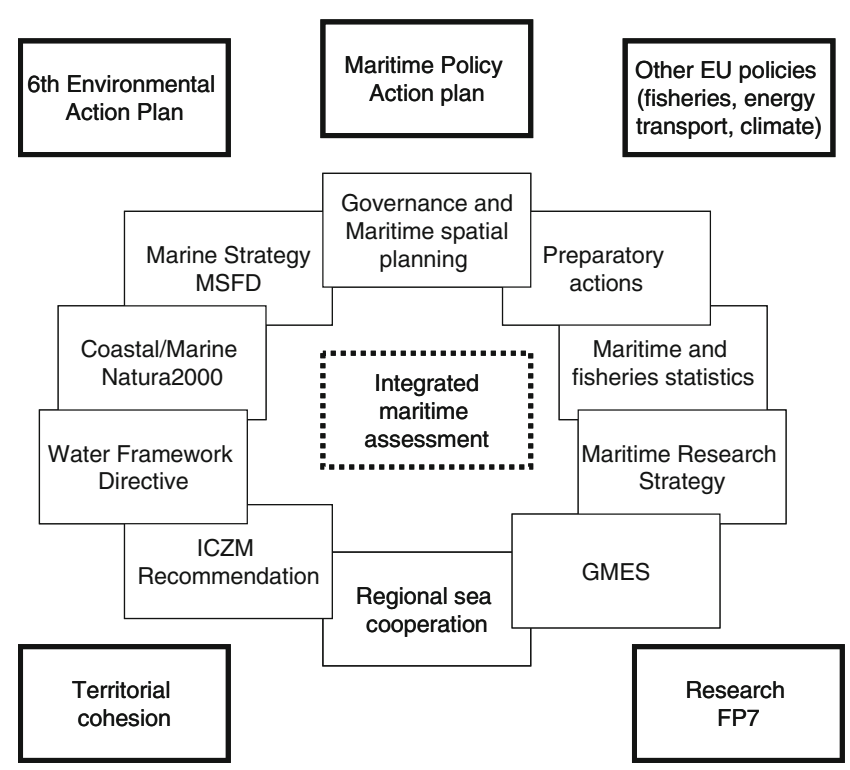

Fig. 1 Integrated maritime assessment in the context of policy areas relevant to coastal and marine environment 
coastal atlases from the Member states and international expert networks (such as International Coastal Atlas Network - ICAN) also contribute to formation of such information system. ICAN experience is in particular important for development of coastal atlases interoperability concept (Dwyer and Wright 2008) that is compliant with implementation rules developed for implementation of European spatial information infrastructure (INSPIRE 2007). It is also directly relevant to formation of water information system for Europe (WISE), in particular its marine section.

\section{Information requirements}

Integrated environmental assessment of coastal zones and maritime space should be focused on sustainability of sea uses and maritime activities by analysing 4 main information blocks:

- Development and pollution pressures that impact coastal and marine areas

- Services that are provided by ecosystems of the coastal and marine areas

- Vulnerability to environmental change (incl. climate) and need for adaptation

- Policy responses and maritime space management (e.g. ICZM and Maritime spatial planning).

To tackle these challenges the emerging information system has to deal simultaneously with building and linking quality assured spatial data sets, developing core sets of indicators for analysis and designing interactive and interoperable information systems.

Coastal and marine assessments will require multidimensional integration of data and information. They should be integrated around the ecosystem approach, focusing on sea regions or sub-regions. Data integration across environmental themes (e.g. land-water-biodiversity) will require spatial units and reference system that can serve as common basis for environmental accounting (change detection), for example coastal and transitional water bodies, river basin districts or coastal regions. Assessment of economic sectors (e.g. maritime transport) should include analysis of environmental concerns. Data integration around cause-effect relations (DPSIR approach) should provide useful links to tie different information bits in to a chain that allows revealing consequences of our actions. This is especially useful in developing capacity for assessing vulnerability of coastal/maritime systems to climate change impacts and needs for adaptation (Fig. 2).

Regional assessments and spatial analysis carried out for terrestrial environment are not useless for analysis of the marine areas. Methodologies, such as land and ecosystem accounting (EEA 2006b) and spatial change monitoring have accumulated and validated experience that can be valuable in this context. Transposing and adapting the analytical frameworks and methods used for land-based analysis to the marine/maritime space is therefore of direct relevance. For example, broad scale seabed habitat mapping can benefit from terrestrial work on dominant landscape types (EEA 2006b).
Fig. 2 Outline of analytical framework for integrated maritime assessment. Note the role of coastal zone as a hinge that links terrestrial and marine areas

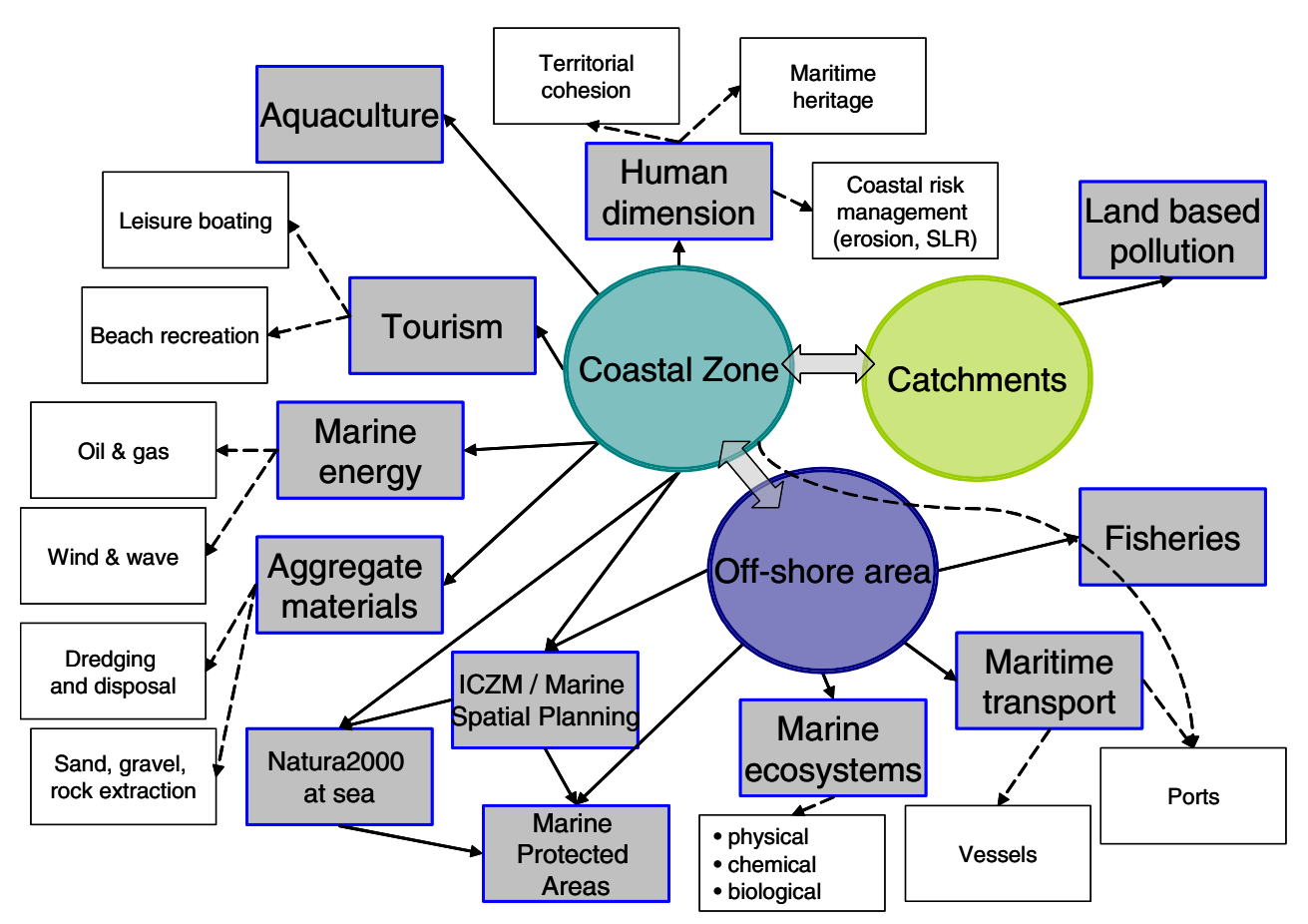


Assessments can benefit from structured data management process that includes data flow streamlining and development of policy relevant indicators. European Commission has offered for the Member states the data and indicator convergence process under auspices of EU ICZM Expert group. Since 2002 the established Working group on indicators and data (WG-ID) has developed 2 types of indicators (European Commission 2002; EEA 2006c). Complex indicator for assessing the progress in ICZM implementation (Pickaver et al. 2004; Pickaver 2008) allows coastal practitioners and managers to assess how well the principles given by the EU ICZM Recommendation has penetrated in to coastal management practice.

Another type of information has been developed around the set of 27 indicators for measuring sustainability of development at coastal zones. These indicators are covering environmental, economic and social aspects of coastal management and also follow the principles given by the EU ICZM Recommendation. This set has been tested by some national coastal observatories (e.g. Lescrauwaet et al. 2006) and most systematically through an Interreg IIIC project (DEDUCE 2007). New research project for 2010 2013 under the EU research framework programme FP7 will continue work on coastal indicators responding to information requirements of ICZM policies in the Mediterranean and the Black sea region. Sustainability indicator set offers opportunity for trans-national comparison and establishing status of coastal zones at European level.

However, sustainability set serves more as a proof-ofconcept and widespread practical use of indicators in coastal management is somewhat hindered by regional diversity of coastal conditions across Europe. These shortcomings have stimulated new approaches that follow more aggregated methodology (Marotta et al. 2008) or more qualitative concept (Pickaver and Salman 2008; EUCC 2008) proven by success of the ICZM progress indicator. Finally, further methodological work to bring the sustainability and the progress indicator together is needed. This would identify improvements in the state of coastal zones as a result of ICZM implementation (European Commission 2007b).

International cooperation is growing among communities dealing with integrated coastal and ocean management indicators (UNESCO/IOC 2006). Marine spatial planning makes use of indicator development in the context of implementing ecosystem-based management approach (UNESCO/IOC 2009) and such initiatives are more and more often found across the globe - China, Australia, North America, Europe, just to name few parts of the world (Douvere 2008). Coastal atlases and cooperation among underlying information systems are driving the data harmonisation and gap identification at national level (Dwyer and Wright 2008). All these developments emphasise importance of data and information systems in the context of sea use management. By aiming at implementation of European Atlas of the Seas and Maritime spatial planning roadmap the EU Integrated Maritime Policy has made a strong resolution towards shared information system for sustainable management of our maritime space.

\section{Conclusion}

Future developments should contribute to better characterization of maritime space and marine ecosystems, hand in hand with GMES Marine Core service and related in situ oceanographic data collection. Data harmonisation, interoperability and access, as promoted by Shared Environmental Information System principles (European Commission $2008 \mathrm{~g}$ ) are no less important in delivering information base for the maritime policy implementation. The main activity lines could be summarized as follows:

- Streamlining monitoring and reporting obligations, collecting data for the prioritized sets of indicators to monitor and report the change in environmental systems. Where possible these indicators should have target values.

- Underpinning physical environment data with systematic collection of relevant socio-economical data, defining the nomenclature of maritime statistical data model. Where feasible, in geo-referenced mode, creating spatial statistics for maritime sectors and human population.

- Integration of stratified space monitoring data with corresponding in situ monitoring of water, biodiversity and physical-chemical parameters in the multi-scale nested approach. Achieving seamless representation for land and seabed data and including the data sets from broad-scale sea bed mapping.

- Information systems - support to formation of European monitoring and data network (EMODNET) and WISE-Marine, interoperability of national coastal atlases and spatial data to support implementation of marine strategies and maritime spatial planning. Due attention should be paid to all information categories, such as reference features, state of environment, operational monitoring and sea uses.

\section{References}

Council (2002) Recommendation of the European Parliament and of the Council of 30 May 2002, concerning the implementation of Integrated Coastal Zone Management in Europe (2002 /413/EC); Brussels, OJ of the European Communities L 148/24.

Council (2008) European Council conclusions, 12 December 2008 (ref: 16503/1/08), The European Integrated Maritime Policy is on 
good track. Available http://ec.europa.eu/maritimeaffairs/press/ press_rel121208 en.html Accessed 22 Dec 2008

DEDUCE $^{-}$(2007) Indicator Guidelines - To adopt an indicatorsbased approach to evaluate coastal sustainable development. Department of the Environment and Housing, Government of Catalonia. Project webpage available http://www.deduce.eu/ Accessed 15 Jan 2009

Douvere F (2008) The importance of marine spatial planning in advancing ecosystem-based sea use management. Marine Policy 32: 759-761. Special issue on the role of marine spatial planning in implementing ecosystem-based sea use management.

Dwyer N, Wright D J (2008) Report of International Coastal Atlas Network Workshop 3 on Federated Coastal Atlases: Building on the Interoperable Approach, European Environment Agency, Copenhagen, Denmark. Available http://ican.science.oregonstate. edu/ican3_final_rpt. Accessed 15 Jan 2009

EEA (2006a) The changing faces of Europe's coastal areas. EEA report 6/2006, Copenhagen.

EEA (2006b) Land accounts for Europe 1990-2000. Towards integrated land and ecosystem accounting. EEA report 11/2006, Copenhagen.

EEA (2006c) Report on the use of the ICZM indicators from the WG ID: A contribution to the ICZM evaluation. Available http://ec.europa. eu/environment/iczm/pdf/report wgid.pdf Accessed 15 Jan 2009

EEA (2008) Ecosystems services - accounting for what matters. EEA Briefing 02/2008. Available http://reports.eea.europa.eu/ briefing 2008 2/en/EN BRIEFING 22008 Accessed 15 Jan 2009

EUCC - The Coastal Union, 2008. QualityCoast - Guide for Entrants. Available http://www.qualitycoast.net Accessed 15 Jan 2009

European Commission (2000) Communication from the Commission to the Council and the European Parliament on integrated coastal zone management: A strategy for Europe. Brussels COM 547 final.

European Commission (2002) Expert group ICZM Recommendation, Minutes of the 1st Meeting, 3 October 2002, Brussels. Available http://ec.europa.eu/environment/iczm/pdf/exgrp_021003.pdf Accessed 15 Jan 2009

European Commission (2005) Thematic Strategy on the Protection and Conservation of the Marine Environment. Brussels COM (2005) 504 final.

European Commission (2006a). Green Paper - Towards a future Maritime Policy for the Union: A European vision for the oceans and seas. Brussels COM(2006)275 final.

European Commission (2007a) Communication from the Commission to the European parliament, the Council, the European economic and social committee and the Committee of the Regions - An Integrated Maritime Policy for the European Union. Brussels $\operatorname{COM}(2007) 575$ final.

European Commission (2007b) Communication from the Commission Report to the European Parliament and the Council: an evaluation of Integrated Coastal Zone Management (ICZM) in Europe. Brussels COM(2007)308 final.

European Commission (2008a) Guidelines for an Integrated Approach to Maritime Policy: Towards best practice in integrated maritime governance and stakeholder consultation $\operatorname{COM}(2008) 395$ final. Available http://ec.europa.eu/maritimeaffairs/pdf/com08_395_en. pdf Accessed 15 Jan 2009

European Commission (2008b) Communication on A European strategy for marine and maritime research — a coherent European Research Area framework in support of a sustainable use of oceans and seas, COM(2008)534final. Available http://ec. europa.eu/research/press/2008/pdf/com_2008_534_en.pdf Accessed 15 Jan 2009

European Commission (2008c) Roadmap for Maritime Spatial Planning: Achieving Common Principles in the EU. COM (2008) 791 final. Available http://ec.europa.eu/maritimeaffairs/ spatial_planning_en.html Accessed 15 Jan 2009
European Commission (2008d) Legal aspects of maritime spatial planning. Framework Service Contract, No. FISH/2006/09 LOT2 Final Report to DG Maritime Affairs \& Fisheries. Available http://ec.europa.eu/maritimeaffairs/pdf/legal_aspects_msp_ report en.pdf Accessed 16 Dec 2008

European Commission (2008e) Offshore Wind Energy: Action needed to deliver on the Energy Policy Objectives for 2020 and beyond. COM (2008) 768 final. Available http://eur-lex.europa.eu/LexUriServ/ LexUriServ.do?uri=COM:2008:0768:FIN:EN:PDF Accessed 15 Jan 2009

European Commission (2008f) Global monitoring for Environment and Security (GMES): we care for a safer planet. COM(2008) 748 final.

European Commission (2008g) Towards a Shared Environmental Information System (SEIS). Communication from the Commission to the Council, the European parliament, the European Economic and Social Committee and the Committee of the regions Brussels, COM(2008) 46 final.

European Commission (2009a) The European Union Strategy for the Baltic Sea Region.Communication from the Commission to the Council, the European parliament, the European Economic and Social Committee and the Committee of the regions Brussels, $\operatorname{COM}(2009) 248$ final.

European Commission (2009b) Progress report on the EU's Integrated Maritime Policy. Communication from the Commission to the Council, the European parliament, the European Economic and Social Committee and the Committee of the regions Brussels, $\operatorname{COM}(2009) 540$ final.

European Commission (2009c) Towards an Integrated Maritime Policy for better governance in the Mediterranean. Communication from the Commission to the Council, the European parliament, the European Economic and Social Committee and the Committee of the regions Brussels, $\operatorname{COM}(2009) 466$ final.

EWEA (2009) Oceans of Opportunity - Harnessing Europe's largest domestic energy resource, European Wind Energy Association, September 2009. Available http://www.ewea.org/fileadmin/ ewea_documents/documents/publications/reports/Offshore Report 2009.pdf Accessed 15 Oct 2009

Halpern B S et al (2008) A Global Map of Human Impact on Marine Ecosystems. Science Vol. 319 no 5865:948-952.

INSPIRE (2007). Directive 2007/2/EC of the European parliament and of the Council of 14 March 2007 establishing an Infrastructure for Spatial Information in the European Community (INSPIRE).

Lescrauwaet A K, Mees J, Gilbert C R (2006) State of the coast of the southern North Sea: an indicators-based approach to evaluating sustainable development in the coastal zone of the Southern North sea. VLIZ Special publication 36. Flanders Marine Institute (VLIZ), Oostende, Belgium.

Marotta L, Cecchi A, Ridolfi E, Breton F, Ceccaroni L (2008) Downscaling indicators of integrated coastal zone management in the Mediterranean Sea. In: Proceedings Littoral 2008. CORILA/ EUCC, Venice.

Molnar JL, Gamboa RL, Revenga C, Spalding MD (2008) Assessing the global threat of invasive species to marine biodiversity. Frontiers in Ecology and the Environment: Vol. 6(9):485-492. doi:10.1890/070064

MSFD (2008) Directive 2008/56/EC of the European parliament and of the Council of 17 June 2008 establishing a framework for community action in the field of marine environmental policy (Marine Strategy Framework Directive).

MyOcean (2008) MyOcean - a FP7 EU project. Available http:/ www.globcolour.info/workshop_200811 presentations/3 Future/ MyOcean_Novembre_2008_Santoleri.pdf Accessed 5 Jan 2009

Pickaver AH, Gilbert C, Breton F (2004) An indicator set to measure the progress in the implementation of integrated coastal zone management in Europe. Ocean \& Coastal Management 47:449-462 
Pickaver A (2008) Further testing of the approved EU indicator to measure the progress in the implementation of integrated coastal zone management in Europe. In: Dahl E, Moksness E, Støttrup J (eds) Proceedings of the International Symposium on Integrated Coastal Zone Management, 10-14 June 2007. Norway. Blackwell Publishing, Arendal

Pickaver A, Salman A H P M (2008) EU Policies and ICZM implementation in Europe: furthering and measuring sustainability. In: Proceedings Littoral 2008, CORILA / EUCC, Venice.

Spalding MD, Fox HE, Allen GR, Davidson N, Ferdaña ZA, Finlayson M, Halpern BS, Jorge MA, Lombana A, Lourie SA, Martin KD, McManus E, Molnar J, Recchia CA, Robertson J (2007) Marine Ecoregions of the World: a bioregionalization of coast and shelf areas. BioScience 57:573-583

Selman M, Greenhalgh S, Diaz R, Sugg Z (2008) Eutrophication and hypoxia in coastal areas: A global assessment of the state of knowledge. WRI Policy note, Water Quality: Eutrophication and Hypoxia No. 1. Available http://pdf.wri.org/ eutrophication_and_hypoxia_in_coastal_areas.pdf Accessed 15 Jan 2009
Sherman K, Alexander LM, Gold BD (eds) (1993) Large marine ecosystems: stress, mitigation and sustainability. Publisher AAAS Press, Washington, DC

Schäfer N (2008). Maritime Spatial Planning — an implementation tool for the Integrated EU Maritime Policy. Coastline 17(2/3):1517. EUCC, Leiden.

UKIE (2008) The EU Strategy for Baltic Sea Region. UKIE Analytical series No. 19. Office of the Committee for European Integration, Department of Analysis and Strategies. Warsaw.

UNESCO/IOC (2006) A handbook for measuring the progress and outcomes of integrated coastal and ocean management. IOC Manuals and Guides, 46; ICAM Dossier 2, Paris.

UNESCO/IOC (2009) Marine spatialplanning: a step-by-step approach toward ecosystem-based management. IOC Manuals and Guides, 53; ICAM Dossier 6, Paris.

UNEP/MAP (2008) Protocol on Integrated Coastal Zone Management in the Mediterranean to the Convention for the Protection of the Marine Environment and the Coastal Region of the Mediterranean, pp 1-89. Available http://195.97.36.231/dbases/webdocs/ BCP/ProtocolICZM08_eng.pdf. Accessed 15 Jan 2009 